\title{
The Application of Micro-class -- Flipped Classroom Model in English Phonetics Classroom Teaching
}

\author{
Xin Dou \\ School of Foreign Languages, Xijing University, Shaanxi, China \\ Keywords: Micro class; Flipped classroom; English phonetics; Teaching mode \\ Abstract: With the continuous development of information technology and teaching \\ concept, micro-class flipped classroom as an emerging and open teaching mode has \\ gradually attracted the attention of academic circles and teachers. This new teaching mode \\ has overturned the traditional teaching mode and process, which has helps greatly in \\ cultivating the awareness of independent learning and improving the students' interest and \\ teaching effect. The traditional teaching mode of English phonetics have not met the needs \\ of teaching. At the same time, the new model based on micro-class flipped classroom can \\ realize multiple functions in classroom teaching, such as relocating the role of teachers and \\ students, stimulating students' autonomy in learning, improving learning efficiency and \\ promoting internalization of knowledge.
}

\section{Introduction}

In recent decades, multimedia devices have been used in most classrooms and look good on the outside, but the classroom teaching haven't really changed. The classroom is affected by the traditional education concept, and teachers are bound by the traditional teaching mode. So, the education is still unable to get rid of the shackles. In 2007, Jonathan Bergmann and Aaron Sims, chemistry teachers in Woodland Park High School, Colorado, adopted the "flipped classroom" teaching model in class. And then, this teaching model was extended to American primary and secondary schools education. In 2011, with the rise of "flipped classroom" teaching mode in the United States, "flipped classroom" quickly attracted the attention of education departments in various countries. This new teaching mode overturns the traditional classroom teaching, and at the same time which makes the university teachers see the new hope in teaching reform. Flipped classroom is a term translated from "Flipped Class Model" (or inverted classroom), which is also known as "inverted classroom mode" or "inverted classroom", and FCM is the short name. The basic ideas have reversed the traditional learning process. Students must finish the learning knowledge points before class, and the classroom becomes an interactive place between teachers and students, which is mainly used to solve doubts, report and discuss. This teaching method can achieve better teaching results. However, the micro class is an important carrier of this subversive learning style. Micro course refers to a small course within 10 minutes, which has clear teaching objectives, short content and concentrated explanation. 


\section{The limitations of traditional teaching mode in English Phonetics}

The British phonetician Gimson A. C. discussed the importance of speech sounds. "To learn any language, one needs only $50-90 \%$ grammar, $1 \%$ vocabulary is enough, but phonetic knowledge must be nearly 100\%", which fully illustrates the importance of phonetics. Language is not only an important part of language learning, but also the starting point. However, Chinese phonetic teaching is only a very small proportion in English teaching. China's education system does not provide comprehensive, systematic and effective training for students' pronunciation. This also leads to errors in the actual phonetic teaching.

\subsection{Phonetic learning is the learning of vowels and consonants}

Traditional phonetic teaching mainly focuses on phonetic phoneme teaching, and ignores phonemes such as rhythm, intonation and speed etc. which can play an important role in communication. Phonetic teaching should not only focus on phonemes, but also on communicative purposes. Students can experience the content and thought from phonetic expression, such as language rhythm, intonation core , intonation rise and fall, the changes of phonemes in words, etc. Through this way of learning, students can achieve the goal of smooth communication.

\subsection{Phonetic learning is a waste of time}

In traditional phonetic teaching, teachers focus on individual factors. Students learning phonetics is only for phonetics. So, when the pronunciation is not the same in daily communication, it will lead to communication barriers. Chinese students can't keep up with the teaching progress in English pronunciation learning, because they are affected by dialects and teaching conditions. So, they lose confidence in phonetic learning and gradually think that phonetic learning is a waste of time.

\subsection{Phonetic teaching is too boring}

At present, the English pronunciation classroom teaching mode is relatively simple, which leads to the pronunciation teaching boring. The traditional teaching mode is teacher explanation, student follow-up, error correction by teachers and student practice. In the phonetic class, teachers have lost the passion and vitality of innovative teaching methods under multiple explanations. This series of activities can't mobilize the enthusiasm of students, such as monotonous follow-up reading exercises, error correction by teachers. All these reasons are that students and teachers have enough interest and attention to phonetic teaching, which leads to students gradually getting bored with phonetic learning.

\section{English phonetics teaching under Micro class -- flipped classroom mode}

\subsection{The meaning and characteristics of micro class}

Micro class was proposed by David Penrose of SAN Juan college in 2008, which is a kind of classroom teaching video with micro video. It includes supporting and expanding resources such as teaching design, courseware, test practice, teaching reflection, and student feedback. Which form a semi-structured, open, situational, thematic and auxiliary teaching resources. Micro-course is based on micro-teaching video as the main carrier. A new online video course designed and developed for a certain knowledge point (such as key points, difficulties, doubts, test points, etc.) or teaching link 
(such as learning activities, topics, experiments, tasks, etc.), which is a situational learning methods.

\subsection{Overview of flipped classroom}

Flipped classroom presented by Bergmann \& Sams is the reversal of traditional teaching mode, which are teachers' classroom teaching and students' after-class practice. Students use short teaching video to complete relevant knowledge and concept learning before class. Carry out other learning activities in class time, such as mutual learning, cooperative learning, answering questions, reporting and discussion, practice and practice, etc. Which means that traditional classroom knowledge is transferred to pre-class completion, and the understanding of knowledge is transferred from homework to classroom learning activities. The teaching mode of flipped classroom mainly includes pre-class activities and classroom activities. Pre-class activities are mainly the following kinds of learning activities, such as watch and learn micro lessons, record the problems of micro-class learning, ask for help through online platforms or parents. Classroom activities help students to absorb and digest more knowledge. The teacher answers the questions in micro-course learning, and then guides the students to discus, practice and give feedbacks in class.

\subsection{English phonetics micro-course -- flipped classroom teaching mode design}

Information technology has become a solid foundation for the development and design of English phonetics Micro class -- flipped classroom teaching mode. Most English teachers can use modern teaching methods to complete the micro course video production. Most students also have the ability to operate electronic devices, and can use the Internet to obtain a variety of learning resources. English phonetic learning requires a lot of imitation and practice, but students can't feel the fun of phonetic learning under traditional mechanical training. Micro-course -- flipped classroom teaching mode enables students to intuitively see and feel changes in mouth shape, tongue position, vocal cord vibration and other changes after class. Teachers can design a variety of classroom exercises and practices to guide students, such as English recording and reading, English movie dubbing, English speech imitation, singing English songs, etc. In this way, students' ability of voice communication in communicative situations is cultivated.

\subsection{The advantages and significance of English phonetics micro course -- flipped classroom teaching mode}

Micro class -- flipped classroom is a new teaching mode compared with traditional teaching mode. The teaching mode repositioned the roles of teachers and students, which is help to stimulate students' independent learning interest and improve their learning efficiency. Micro-course -flipped classroom mode is a student-centered teaching mode. The premise of this teaching mode is that students have a strong independent learning awareness and interest. Students can master the time and rhythm of learning independently by themselves, so they can adjust the time, progress and frequency of micro-course learning according to the level of knowledge. Micro-course -- flipped classroom teaching mode overturns the traditional teaching process. It arranges practical exercises and knowledge application in class.

\section{Conclusions}

English phonetics Micro course -- flipped classroom teaching mode is a new teaching method based on modern information technology. Its main purpose is to solve many problems in the traditional teaching mode. This teaching mode can promote the learning of pronunciation and 
intonation, and it is help for cultivating students' ability to communicate in the actual context. Rebuilding the role of teachers and students is a major breakthrough in this new teaching mode. But at present, there is relatively little theoretical and practical experience about this model. In the whole implementation process, there will also be some problems that need to be solved urgently. Students may be interfered by others or other activities when they are learning micro-lessons. So, how to effectively monitor the results of students' micro-lessons has become a new research direction. English phonetics Micro course -- flipped classroom teaching mode has many advantages, such as cultivating students' awareness of independent learning, improving teaching effect, and promoting the absorption of knowledge, but it still needs to be constantly summarized and improved in practice.

\section{References}

[1] Mehring, Jeff. Present Research on the Flipped Classroom and Potential Tools for the EFL Classroom [J]. Computers in the Schools. 2016, Vol. 33 Issue 1, p1- 10.

[2] Melanie T. Jacot \& Jason Noren \& Zane L. Berge (). The Flipped Classroom Training and Development: Fad or the Future? [J]. Performance Improvement. 2014, Vol.53 Issue 9, p23-28.

[3] Gimson, A. C. An Introduction to the Pronunciation of English [M]. London: Edward Arnold, 1980.

[4] Hu tiesheng, huang mingyan, li min. Three stages of micro-course development and its enlightenment in China [J]. Journal of remote education, 2013 (4): 36-42. 